\title{
Climate Change Dry Spell Impact on Agriculture in Salyantar, Dhading, Central Nepal
}

\author{
Pramila Paudyal $^{1}$, Dinesh Raj Bhuju ${ }^{2}$ and Manoj Aryal ${ }^{3}$ \\ ${ }^{1}$ Central Department of Environmental Science, Tribhuvan University, Kathmandu,Nepal \\ ${ }^{2}$ Nepal Academy of Science and Technology, Lalitpur, Nepal \\ ${ }^{3}$ Environment Division, Ministry of Science, Technology and Environment, Kathmandu, Nepal \\ e-mail: paudyalpramila@gmail.com
}

\begin{abstract}
Understanding the problem increasingly posed by climatic change is one of the critical challenges of our time. A study was carried out in Salyantar village in Dhading district of central Nepal to understand and assess the extent of climate change impacts on agriculture. The impact assessment was performed through analysis of meteorological data, Landsat images, and people's perception on changes relative to agriculture sector. Mann-Kendall statistical trend test was used to assign statistical significance to the trend whereas temperature vegetation dryness index (TVDI) was used to identify soil moisture condition as an assessment criterion. The perception of local people on climate change and its impacts was studied through generalized questionnaire survey and participatory rural appraisal. The results of the study portrayed rise in temperature in the study area in the recent years in comparison to the past. The maximum temperature increment was $0.03 \mathrm{p} \mathrm{C}$ per year. As for precipitation, it showed decreasing trend by $1.855 \mathrm{~mm}$ per year. The TVDI obtained from Landsat image, showed decreasing trend of soil moisture in different years, which indicate an increased longer dry spell. This has unswerving effect on agriculture as the entire Salyantar village is dependent upon rain-fed agriculture. The perceived impacts on agriculture were decreased crop yield, reduced soil moisture, and increased incidence of new pests and invasive plant species. Such impacts were fairly heterogeneous in distribution. The Salyantar village, a raised flat-land of river deposition already stuck in the grip of water stress, was found exacerbated by the effect of climate change.
\end{abstract}

Key words: agriculture, landsat images, Mann-Kendall test, temperature vegetation dryness index

\section{Introduction}

Climate change is now recognized as one of the most serious challenges, which the world its people, the environment and its economies are facing. The main characteristics of climate change are: rise in average global temperature, changes in cloud cover and rainfall, particularly over land, melting of ice caps and glaciers and reduced snow cover, and increase in ocean temperatures and ocean acidity due to seawater absorbing heat and carbon dioxide from the atmosphere (UNFCCC 2007). In this case, agriculture becomes one of the most vulnerable sectors to be affected by the anticipated climate change. The predicted changes in temperatures and rainfall patterns, as well as their associated impacts on water availability, pests, diseases, and extreme weather events are likely to affect substantially the potential of agricultural production (ADBI 2012). There is no doubt that climate change is impacting developing country like Nepal rather disproportionately in the view of the country's state of development. The rapidly retreating glaciers, sharp rise in average temperature of $0.06^{\circ} \mathrm{C}$ per annum (MOE 2012), increasing trend of extreme rainfall events and consequences of devastating floods and droughts are some of the effects Nepal has faced during the last few years.

Nepalese agriculture is predominantly small-scale farming where $46.5 \%$ of overall cultivated area is irrigated while only $69.5 \%$ of total irrigable area is irrigated (MOE, 2012) and around half of which is dependent on natural rainfall. In this relation some 
studies have also been conducted in the vicinity of Dhading district. The report by Siddiqui et al. (2012) revealed that the catchment of Budhi Gandaki is highly vulnerable to changing climatic situation. Ecologically the area is much sensitive with the value of 0.615-1.00. In accordance with SAGUN (2009) the impact of climate change and its effect in Dhading is very much pronounced. Tamrakar et al. (2010) also agreed the decreasing production of agricultural yield in Dhading district. In addition Sharma (2014) reported the impact of climate change was severe but the people were illequipped to the adaption. Furthermore, the research exposed the integrated nature of the farming systems in Dhading district. The prolonged winter droughts had led to the drying of water sources as well as affecting soil preparation in the district. Because of such consequences of climate change, it is important to understand the effects at the local level. Even though many studies on climate change have been carried out, impacts of climate change and dry spell at the local level have not been quantified much yet.

The present study was carried out with a broad objective to analyze the trend of climate change and to assess the impacts of dry spell on agriculture in Salyantar village of Dhading district in central Nepal. The specific objectives of the study were to: (i) analyze the trends of temperature and precipitation in the study area, (ii) assess the status of soil moisture of the study area and analyze the trend of existing drought, and (iii) study the impacts of climate change dry spell on agricultural productivity with respect to local people's perception and verify with available data.

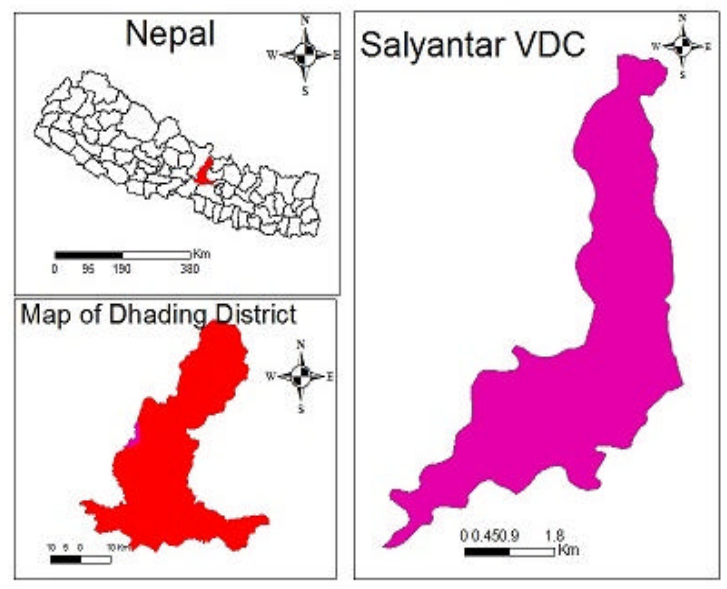

Fig. 1. Map of study area Salyantar, Dhading

\section{Methodology \\ Study area}

The study area was Salyantar village settlement in Dhading district of central Nepal (Fig. 1). The village is on raised flatland "Tar" of river deposition, spreading from $27.99^{\circ} \mathrm{N}$ to $84.81^{\circ} \mathrm{E}$. It is surrounded by four rivers, Budhigandaki in west, Netrawoti (Aankhu Khola) in south, Hyaping in east and Kaste in North.

\section{Methods \\ Meteorological data}

The meteorological data used in the research included precipitation and temperature data from the nearby station, Dhunibesi (DHM 2014). Temperature data from 1979-2013 were collected whereas precipitation data were collected from 1979- 2008. There was no record of precipitation data after the year 2008 due to the flood which inundated the meteorological station in Arughat. For the analysis of climatic parameters (temperature and precipitation) Mann- Kendall t-test was carried. Software used for performing the MannKendall statistical test was Addinsoft's XLSTAT 2013.

Soil moisture. The soil moisture was calculated from the different Landsat images obtained from USGS website. The images of the different year 1990, 2000 and 2010 were analyzed to calculate soil moisture through the calculation of Temperature Vegetation Dryness Index (TVDI) from the Landsat images. Landsat image for the year 1990 was obtained from Landsat 4, for the year 2000 Landsat 7 was used and for the year 2010 the image was obtained from Landsat 5 . Thermal band (known as band 6) was used to know the soil moisture of the study area. For the calculation of soil moisture from Landsat image different steps were followed. First the land surface temperature was calculated followed by Normalized Difference Vegetation Index (NDVI). From the relationship of Land surface temperature (LST) and NDVI, TVDI was obtained which helped to know the level of soil moisture from the Landsat images. The TVDI was calculated for three different time series: 1990, 2000 and 2010, and it was derived using the formula as follows:

$\mathrm{TDVI}=\frac{L S T-L S T \text { min }}{L S T \max -L S T \min }$

Where,

LST is the surface temperature of a given pixel with triangle. 
$\mathrm{LST}_{\min }$ is minimum surface temperature, which defines the wet edge in triangle obtained by linear regression fit.

$\mathrm{LST}_{\max }$ is the maximum temperature obtained by a linear regression fit.

The TVDI provides information on spatial distribution of wetness at the surface level. The value of TVDI ranges from 0 to 1 . The greater the value of TDVI, the lower the soil moisture and higher will be the drought level (Meng et al. 2008).

Along with the use of Landsat data for the retrieval of soil moisture, laboratory analysis of soil samples was also carried. Twelve different samples were taken from the study site randomly from different places like nearby water sources, agricultural land and near dried aahal area (area that was previously a pond for domestic animals).

People's perception. To get people's perception on various parameters relating to climate change and its impacts, the questionnaires were prepared and participatory rural appraisal (PRA) was carried out to collect information from the people. Focused group discussion (FGD) and key informant interview (KII) were applied to understand people's perception on climate change and its impacts. The FGD was carried out in Salyantar, and included 11 participants (six male and five female). The KII involved 12 persons who included: chairperson of users' group, representative of women groups, social mobilizer, agriculture technician (JTA) and teachers. They were asked all the necessary questions relating to climate, climate change, climatic trends, climate induced disasters, its

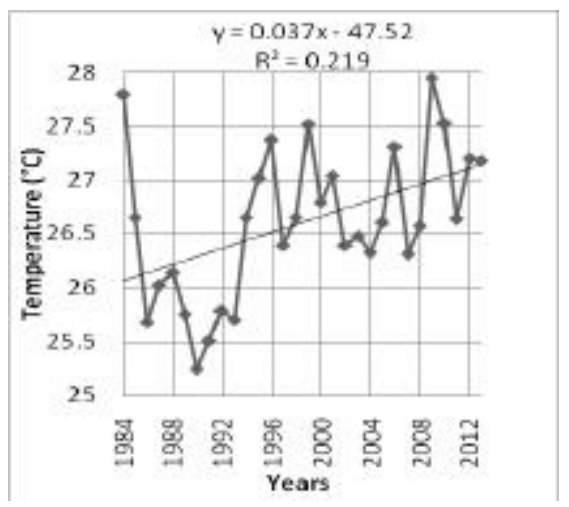

Fig. 2. Maximum temperature trend of Dhading district obtained from Dhunibesi station (Data source: DHM, 2014) impact, impact on agriculture. The checklist and questionnaires were prepared for the interview. The sample size ( 90 households) was determined using formula given by Arkin and Colton (1963). The published and unpublished documents were assessed for secondary data collection.

\section{Results and Discussion Meteorological data analysis Temperature trends}

The temperature analysis of 30 years of Dhading district obtained from Dhunibesi station showed that the maximum temperature was increasing at the rate of $0.03^{\circ} \mathrm{C}$ per year and that the trend was statistically significant (Fig. 2). The analysis of trend of minimum temperature showed that the trend was nearly constant with increment of $0.009^{\circ} \mathrm{C}$ per year and statistically insignificant. While analyzing the seasonal temperature trend, the analysis of pre-monsoon mean temperature trend showed increasing at $0.017^{\circ} \mathrm{C}$ per year and that of monsoon mean temperature $0.052^{\circ} \mathrm{C}$ per year and trend was statistically significant.

\section{Precipitation trends}

Precipitation data of 30 years from 1979 to 2008 were analyzed to observe the long term trend in precipitation taken from Arughat station. The average annual trend was observed and found to be decreasing at the rate of $1.85 \mathrm{~mm}$ per year and was statistically significant. The seasonal precipitation analysis showed the maximum contribution $81 \%$ was on the monsoon season followed by pre monsoon season and the least contribution was on winter as well as post monsoon season (Fig. 3).

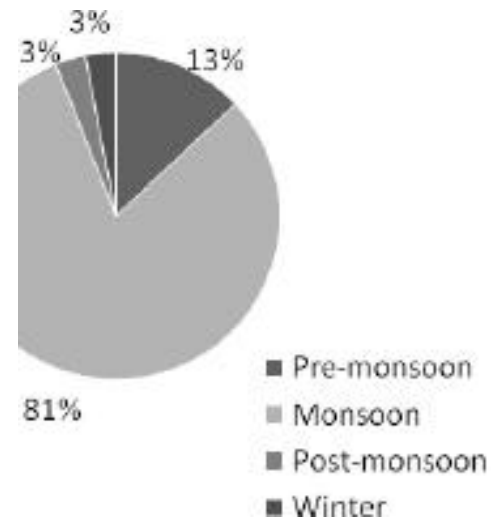

Fig. 3. Seasonal precipitation of Dhading district ( Data source: DHM, 2014) 
Nepal Journal of Science and Technology Vol. 16, No.1 (2015) 59-68

Table 1. Results of Mann- Kendall test statistics

\begin{tabular}{|c|c|c|c|c|c|c|c|c|c|}
\hline \multirow[t]{2}{*}{$\mathbf{S N}$} & \multirow{2}{*}{\multicolumn{2}{|c|}{ Parameters }} & \multirow{2}{*}{$\begin{array}{l}\text { Linear } \\
\text { trend } \\
\text { line } \\
\text { slope }\end{array}$} & \multicolumn{4}{|c|}{ Mann-Kendall test statistics } & \multirow{2}{*}{$\begin{array}{c}\text { Response } \\
\text { Trend }\end{array}$} & \multirow[t]{2}{*}{ Rem. } \\
\hline & & & & & Kendall's & n-value & Alnha & & \\
\hline \multirow[t]{6}{*}{1} & Temperature & Maximum & 0.037 & 0.044 & 0.316 & 0.015 & 0.05 & $\bar{I}$ & $\mathrm{~S}$ \\
\hline & & Minimum & 0.009 & 0.008 & 0.090 & 0.498 & 0.05 & I & NS \\
\hline & & Pre-monsoon & 0.017 & 0.052 & 0.256 & 0.05 & 0.05 & I & $\mathrm{S}$ \\
\hline & & Monsoon & 0.052 & 0.053 & 0.436 & 0.001 & 0.05 & I & $S$ \\
\hline & & Post-monsoon & 0.017 & 0.024 & 0.132 & 0.317 & 0.05 & I & NS \\
\hline & & Winter & 0.014 & 0.015 & 0.087 & 0.509 & 0.05 & I & NS \\
\hline \multirow[t]{5}{*}{2} & Precipitation & Annual & -2.995 & -2.756 & -0.255 & 0.049 & 0.05 & $\mathrm{D}$ & $\mathrm{S}$ \\
\hline & & Pre-monsoon & -1.475 & -1.33 & -0.076 & 0.572 & 0.05 & $\mathrm{D}$ & NS \\
\hline & & Monsoon & -19.42 & -9.113 & -0.214 & 0.101 & 0.05 & $\mathrm{D}$ & NS \\
\hline & & Post-monsoon & -0.541 & -1.045 & -0.126 & 0.339 & 0.05 & $\mathrm{D}$ & NS \\
\hline & & Winter & -1.549 & -1.547 & -0.218 & 0.094 & 0.05 & $\mathrm{D}$ & NS \\
\hline
\end{tabular}

Abbr. I: increasing; D: decreasing; S: significant; NS: Not significant

The details of Mann-Kendall test for temperature and precipitation is presented in the Table 1 . In the analysis of temperature data of Dhading district, the result was found consistent with that of Duwadi (2012). It showed that there has been $0.097 \%$ per annum increase in temperature of the district between the years of 19782008. The highest and the lowest recorded temperature fortanarydringthisperiodwas 15.8 and $11.45^{\circ} \mathrm{C}$ in 1990 and 1983 respectively. The result obtained showed steadiness with the increasing temperature of Dhading district. In such condition, there is high confidence that the impact will directly hit the water sector and agriculture. Similarly, the SAGUN (2009) analysis of temperature data indicated that average temperature was increasing in Dhading district. Moreover, average temperature increase was higher with increasing elevation.

\section{Estimation of TVDI}

The soil moisture of the study was studied from the obtained results of the scatter plot and NDVI. The soil moisture was found higher in the side of water sources and vegetation, while in the areas with bare land the soil moisture was found less. In the calculation of TVDI, the higher the value of TVDI, lower is the soil moisture and vice-versa. For the year 1990, the value of TVDI ranged from 0.01 to 0.4 for the year 1990 . This moderate value of TVDI indicated reasonable level of soil moisture in the area. For the year 2000, the TVDI value ranged from 0.01 to 0.6 , which was higher than that of the previous decade (1990) and indicated an increased severity of the dry spell compared to 1990. Finally in the year 2010, the TVDI value was found to be 0.7 , which was highest among the three time series. This high TVDI value means low soil moisture condition in the area. Thus, it is interpreted that the rainfall was in the decreasing trend or in other sense, the dry spell increasing. The images of TVDI for all three Landsat images are shown in Figs. 4, 5 and 6.

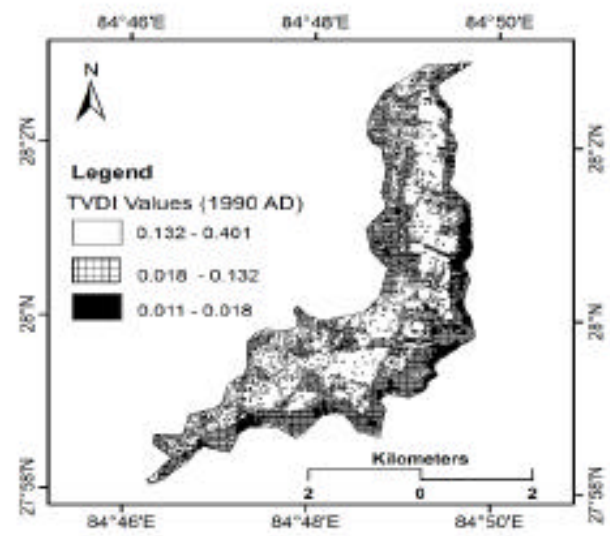

Fig. 4. TVDI map of the year 1990

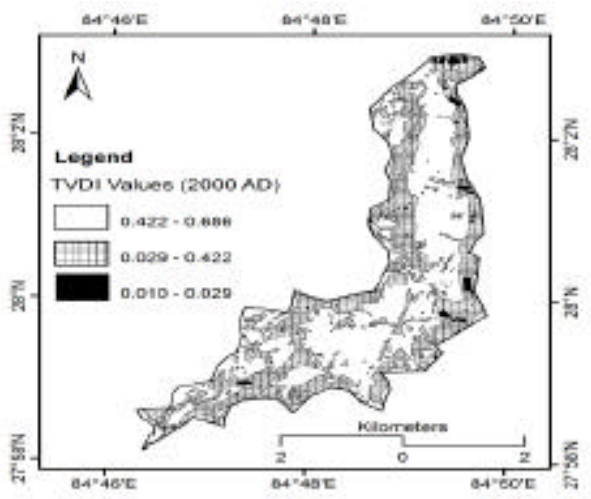

Fig. 5. TVDI map of the year 2000 


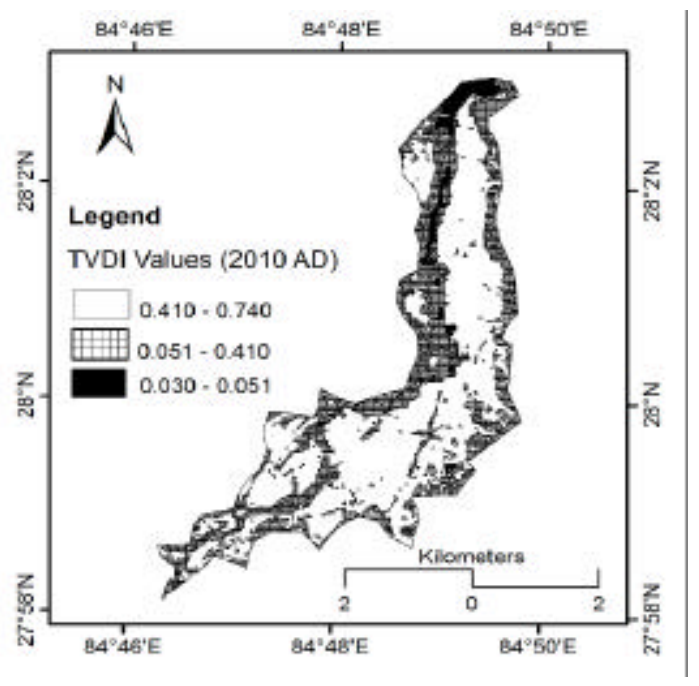

Fig. 6. TVDI map of the year 2010

The results were found consistent with the findings of Li et al. (2012) who had also analyzed the soil moisture condition of to analyze the drought state of the agricultural land in Beijing and found significant relation with the land surface temperature. It was found that higher the land surface temperature, higher was the soil moisture state in the study. In accordance with the research results of Ebrahimi et al. (2010) also found the results of the indicating drought had been increased when the vegetation fraction has been decreased consequently when the research was carried using the Landsat data. In addition, Mekonnen (2009) also estimated the soil moisture using the relationship of LST and NDVI from remote sensing to the ground measured soil moisture and the soil moisture was found higher near the catchment area of the water source.

\section{Laboratory analysis of soil moisture}

From the laboratory analysis, the moisture content of the soil was found very high (28\%) in the agriculture land (khet) (Table 2). This can be attributed to the agricultural land which was irrigated using sprinkles nearby the water source i.e. near Budhi-Gandaki River. In the agricultural land (bari) it was found lowest (10\%) because the sample was away from the access to water sources and continuously suffering from longer dry spell.

Table 2. Moisture content (\%) of soil sample

\begin{tabular}{|c|c|c|c|c|c|c|}
\hline SN & $\begin{array}{l}\text { Sites of soil } \\
\text { collected }\end{array}$ & $\begin{array}{l}\text { Weight of the } \\
\text { paper (g) (W1) }\end{array}$ & $\begin{array}{l}\text { Agr. Wt. of } \\
\text { moist soil (g) } \\
\text { (W2) }\end{array}$ & $\begin{array}{l}\text { Weight of } \\
\text { dry soil in } \\
\text { (g) (W3) }\end{array}$ & W2-W3 & MC\% \\
\hline 1 & $\begin{array}{l}\text { Agricultural } \\
\text { land (bari) }\end{array}$ & Neglected (0) & 70.01 & 61.14 & 8.87 & 14.51 \\
\hline 2 & $\begin{array}{l}\text { Agricultural } \\
\text { land (bari) }\end{array}$ & Neglected (0) & 139.75 & 124.76 & 14.99 & 12.02 \\
\hline 3 & $\begin{array}{l}\text { Agricultural } \\
\text { land (bari) }\end{array}$ & Neglected (0) & 41.57 & 37.49 & 4.08 & 10.88 \\
\hline 4 & $\begin{array}{l}\text { Agricultural } \\
\text { land (khet) }\end{array}$ & Neglected (0) & 33.59 & 28.57 & 5.02 & 17.57 \\
\hline 5 & $\begin{array}{l}\text { Agricultural } \\
\text { land (khet) }\end{array}$ & Neglected (0) & 32.03 & 24.97 & 7.05 & 28.24 \\
\hline 6 & $\begin{array}{l}\text { Agricultural } \\
\text { land (khet) }\end{array}$ & Neglected (0) & 120.75 & 102.01 & 18.74 & 18.37 \\
\hline 7 & $\begin{array}{l}\text { Nearby } \\
\text { Aahal (pond) }\end{array}$ & Neglected (0) & 85.01 & 74.94 & 10.07 & 13.44 \\
\hline 8 & $\begin{array}{l}\text { Nearby } \\
\text { Aahal (pond) }\end{array}$ & Neglected (0) & 88.05 & 75.99 & 12.05 & 15.85 \\
\hline 9 & $\begin{array}{l}\text { Nearby } \\
\text { Aahal (pond) }\end{array}$ & Neglected (0) & 135.80 & 119.71 & 16.08 & 13.44 \\
\hline 10 & $\begin{array}{l}\text { Nearby } \\
\text { water source }\end{array}$ & Neglected (0) & 35.40 & 28.99 & 6.41 & 22.09 \\
\hline 11 & $\begin{array}{l}\text { Nearby } \\
\text { water source }\end{array}$ & Neglected (0) & 50.44 & 42.351 & 8.09 & 19.11 \\
\hline 12 & $\begin{array}{l}\text { Nearby } \\
\text { water source }\end{array}$ & Neglected (0) & 78.04 & 63.523 & 14.52 & 22.86 \\
\hline
\end{tabular}




\section{People's perception}

To know the people's perception on climate change dry spell impact in agriculture a total of 90 households were sampled proportionately from study area, Salyantar village settlement. The detail socio- economic characteristics of the sampled respondent are presented in Table 3. Majority of the responding people aged between 25 and 65 years old. The literate among the respondents were $59 \%$, and $71 \%$ of them were engaged in agriculture.

Table 3. Socio-economic characteristics of surveyed household

\begin{tabular}{l|c|l|c}
\hline Characteristics & Percentage & Characteristics & Percentage \\
\hline Age group & & Occupation & 71 \\
Less than 25 & 2 & Agriculture & 8 \\
$25-49$ & 37 & Business & 10 \\
$45-65$ & 53 & Service & 11 \\
More than 65 & 8 & Labor & 52 \\
Education & 59 & Gender & 48 \\
Literate & 41 & Male & \\
Illiterate & & Female & \\
\hline
\end{tabular}

\section{Impact on agriculture}

The persisting dry spell in the Salyantar area is making the agriculture difficult and at the same time, climate change is aggravating existing conditions. The main food crops produced in the Salyantar are upland rice, locally known as Ghaiya dhan (Oryza sativa), niger (Guizotia abyssinica), Mash (black lentil, Vigna mungo) and maize (Zea mays). Based on these crops, people felt decreasing agricultural productivity, which they thought was due to the changing climatic situation. About $15.3 \%$ of the respondent felt the increased productivity in the area, while $69.4 \%$ of respondent agreed on decreased agricultural productivity in the agriculture sector due to climate change (Fig. 7). Among the four main crops in the area, majority of the respondent agreed on the decreasing productivity. Ghaiya dhan was found to be the most affected crops, where $79.2 \%$ agreed on its decreasing productivity due to changing climatic stress and dry spell, followed by maize and Mash (Fig. 8).

The existing dry spell impact was felt by the local farmers in the study area. Most of the respondents agreed with the reduced soil moisture of the area (Fig. 9). Farmers in the area have also experienced a general increase in pests like padkhe kira commonly called hopper (Nephotettix spp), khumre kira (Phyllophaga spp) etc. coinciding with the periods of drought (Fig.10). However, some of the pests were unknown and new to them. In a study carried out in Ramechhap, Subdei (2014) noted that $18 \%$ of the paddy lands were converted to Bari land due to drought. The study also revealed that cold spells along with increasing foggy days had aggravated the occurrence of pest and diseases affecting winter crops far more than what it used to be in the past. Duwadi (2012) also reported that, people were perceiving the fact of decreasing rainfall every year during winter season, the weather was becoming dry every year, the yearly rain were not supporting crop production as before, climate change had led to crop infestation and diseases, and there was scarcity of the fuel wood.

\section{Impact on water sources}

The major source of water in Salyantar was public tap followed by spring and river respectively. Water scarcity has been a problem in the area. While studying, about $51.4 \%$ of the responding local people opined that the drying of ponds and spring was the main reason of water scarcity in the area. About $18.9 \%$ and $16.2 \%$ of them felt that the main cause low river flow and low rainfall for the scarcity of water. In consistence with the present results, Poudel etal. (2011) also noted local observations and local climate projections both highlighted the increasing temperatures and extreme events, and the seasonal shifts had negative impact on crops of Dhading district. In particular droughts during the sowing period of most agricultural crops have affected not only the timing but also the harvesting season. Prolonged winter droughts led to the drying of water sources as well as affecting soil preparation.

\footnotetext{
SAGUN (2009) stated thet encticrainfall pettems and heil stom execontribatingtothesoil erosion, soil fentility loss, and the cropdanegewerehavingadvenseimpacts on the livelihood of most of theseammunities, this
} 
increasing risk to the food security. Similarly Dhakal et al. (2011) also revealed vegetable farming was the main source of livelihood in Dhading. Less production of rice, including other crops, less juicy fruits, change of sowing and harvesting periods of the crops and fruits was decreasing comparison to past years were observed. Since the weather pattern was unpredictable the yielding of crops and its productivity was becoming unpredictable accordingly. Unknown species of pests and insects were introduced and there has been increased in number of existing insect. The diseases seen in the recent days were also due to the indirect non climatic indicators of climate change. The incidence, range and seasonality of many existing health disorders had been observed increasing in comparison to the past.

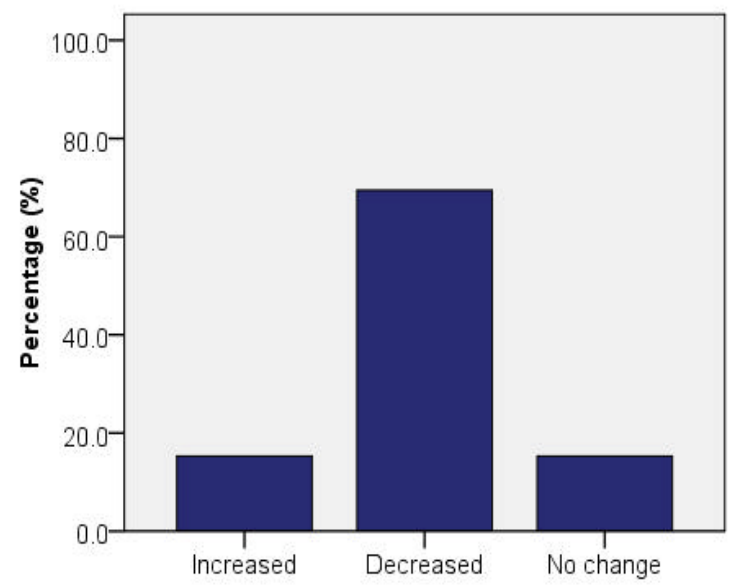

Fig. 7. Perception on status of agricultural productivity

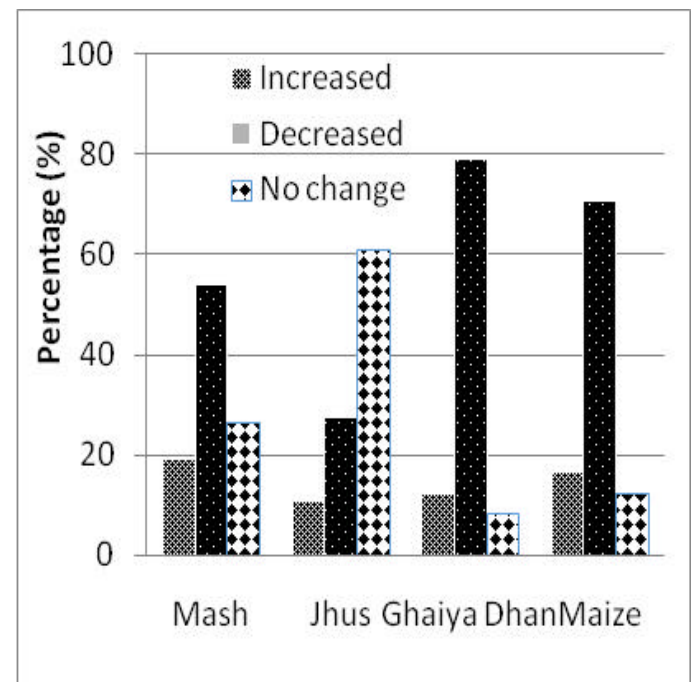

Fig. 8. Perception on change in crop productivity

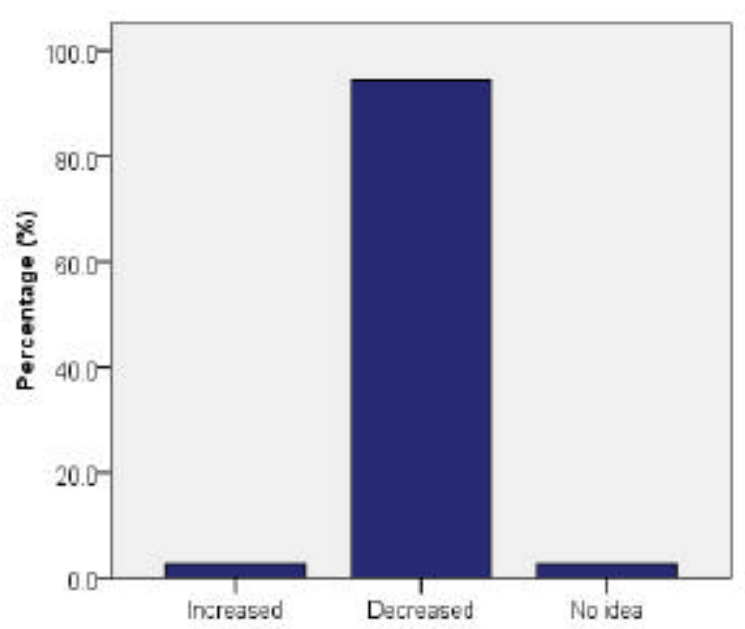

Fig. 9. Perception on change in soil moisture

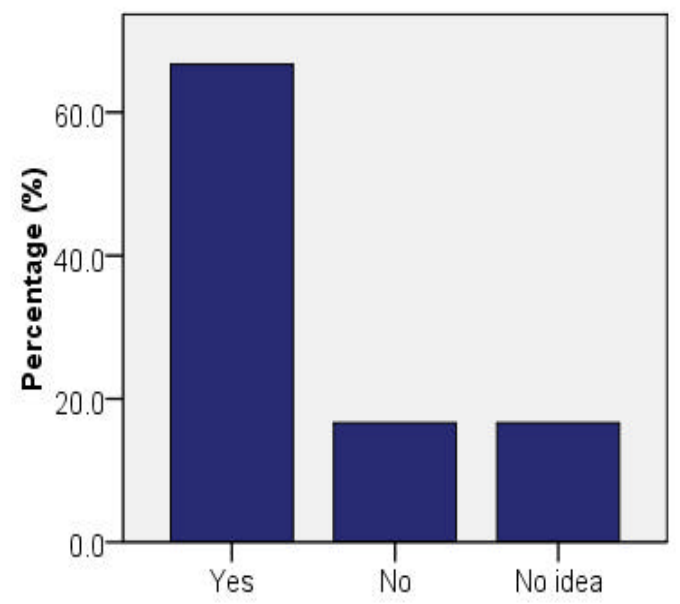

Fig. 10. Perception on availability of new pest

\section{Climate change}

From the analysis of the data, it was found that only $45 \%$ had heard climate change and $55 \%$ of the total respondent had not heard the term of climate change. Of the total household respondents surveyed, $70.8 \%$ had experienced the change in precipitation pattern and intensity. Only $15.3 \%$ felt there was no change in precipitation pattern and $3.9 \%$ of the respondents, felt no change in the behavior and pattern precipitation (Fig. 11). People were feeling the temperature change. Among the total respondent $51.4 \%$ of them felt days were hotter than previous last 20 years. Similarly, $18.1 \%$ of them found summer hot and winter cold. Rest of the respondents said that they had experienced extreme hot summer and experienced winter less cold (Fig. 12). 


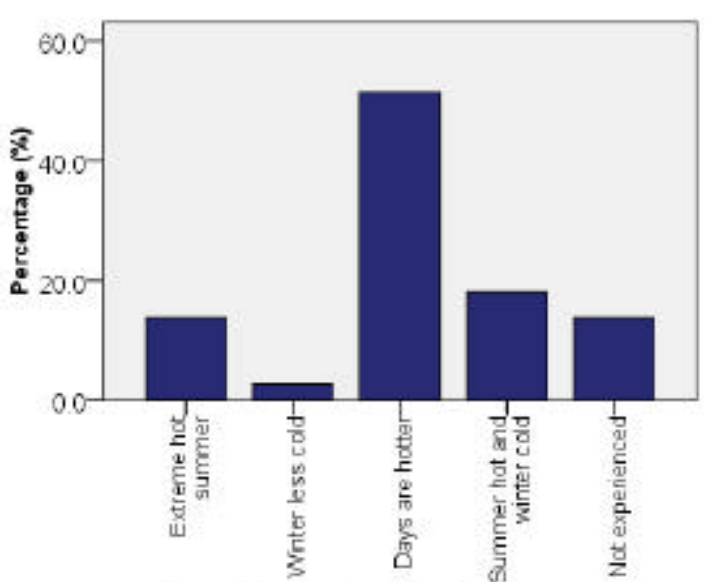

Fig. 11. Perception on precipitation change

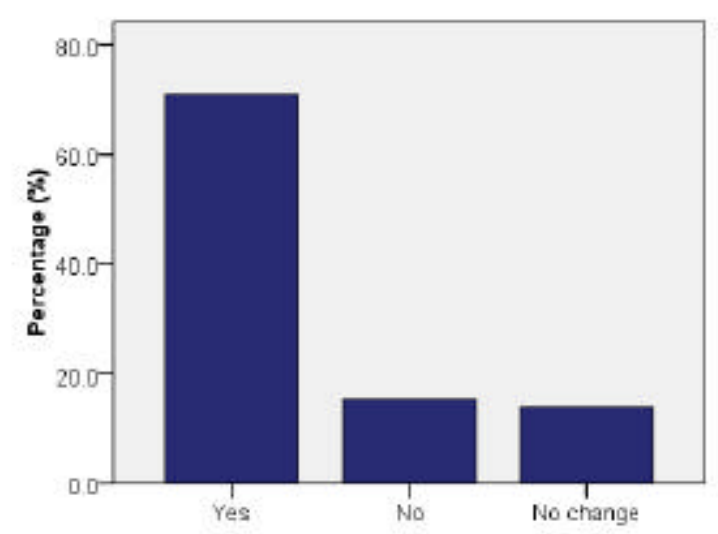

Fig. 12. Perception on changing temperature

Similar results on perception were obtained by Tiwari et al. (2010) on climate change study from Himalaya to Tarai region in which local people, based on their past experience responded that warming days, erratic precipitation patterns, ecological variability, biological change and their adverse effects on human beings had increased. Similarly, Duwadi (2012), Dhakal et al. (2010) reported the perception of local communities saying that warming days had been increasing, precipitation pattern had become more unpredictable, seasons had been changing, frequency of drought had increased, natural water sources had been decreasing and windstorm was getting stronger which was further supported by the report of (SAGUN 2009).

\section{Acknowledgements}

The study was undertaken with the grant support of Strengthening Disaster Risk Management in Academia (SDRMA) project of TU CDES and UNDP. We are thankful to Dr. Moti Lal Ghimire, Ajay Mathema, Bharat Ghimire and Niroj Timilsina for their valuable inputs to the study.

\section{References}

ADBI. 2012. Climate change in Asia and the pacific. Asian Development Bank Institute. Sage Publication, New Delhi.

Arkin, H. and R.R. Colton. 1963. Tables for statisticians. New York: Barnes \& Noble.

Dhakal, K., S. Silwal and G. Khanal. 2010. Assessment of climate change impacts onwater resources and vulnerability in hills of Nepal: a case study on Dhare Khola watershed of Dhading District. A report submitted to National Adaptation Programme of Action (NAPA) to Climate Change, Ministry of Environment, Kathmandu.

Duwadi, S. 2012. Study on impacts of climate change its adaptation and mitigation

form central development region of Nepal. Nepalese Teacher Network for Sustainable Education.

Ebrahimi, M., A. Matkan, and R. Darvishzadesh. 2010. Remote sensing for drought assessment in arid regions (a case study of central part of Iran, "shirkooh-yazd"). $R S$ \& GIS Department, Faculty of Earth Sciences, Shahid Beheshti University (SBU), Tehran.

Li, Z., H. Wu, B.H. Tang, X. Song, and G. Zhou. 2012. Determination of bare surface soil moisture from combined temporal evolution of land surface temperature and net surface shortwave radiation. State Key Laboratory of Resources and Environment Information System, Institute of Geographic Sciences and Natural Resources Research, CAS, Beijing.

Mekonnen, F. 2009. Satellite remote sensing for soil moisture estimation: Gumara catchment, Ethiopia.A thesis submitted to the International Institute of Geoinformation Science and Earth Observation in partial fulfilment of MSC in Geo-information Science and Earth Observation.

Meng, L., Li. J., Chen, Z., and Xi, W. (2008). The calculation of TVDI based on the composite time of pixel and drought analysis. School of Remote Sensing and Information Engineering Wuhan University, Wuhan, China.

MOE. 2012. Mountain environment and climate change in Nepal I. Country report for the International Conference of Mountain Countries on Climate Change. April 5-6, 2012. Ministry of Environment, Kathmandu.

Paudel, B., B.B. Tamang, K. Lamsal, and P. Poudel. 2011. Planning and costing of agricultural adaptation with reference to integrated hill farming systems in Nepal. LI-BIRD, IIED, and SEI

SAGUN. 2009. Climate Change Impacts on Livelihoods of poor and vulnerable communities and biodvirversity 
conservation: A case study in Banke, Bardia, Dhading and Rasuwa districts of Nepal. Sagun Program, CARE Nepal, Kathmandu.

Sharma, A. 2014. A Research on role of biogas on climate change adaptation. A case study from Muralibhanjyang VDC of Dhading district. MSc dissertation submitted to Central Department of Environmental Science, Tribhuwan University, Kathamandu.

Siddiqui, S., L. Bharati, M. Pant, P. Gurung and B. Rakhal. 2012. Nepal: Building climate resilience of watersheds in mountain eco-regions-climate change and vulnerability mapping in watersheds in middle and high mountains of Nepal. ADB Technical Assistance Consultant's Report for Department of Soil Conservation and Watershed Management (DSCWM), Government of Nepal

Subedi, R.C. 2014. Climate variability and livelihoods of the farmers in rural Chisapani, Ramechhap of Nepal.
MSc dissertation submitted to Central Department of Environmental Science, Tribhuvan University, Kathmandu.

Tamrakar, A.S., P. Koirala and P. Shrestha. 2010. Knowledge, practice and use of pesticides among commercial vegetable growers of Dhading district, al.The Journal of Agriculture and Environment, 11: $95-100$.

Tiwari, K.R., K.D. Awasthi, M.K. Balla and B.K. Sitaula. 2010. Local people's perception on climate change, its impact and adaptation practices in Himalaya to Tarai regions of Nepal. [Available at: http:// www.forestrynepal.org/publications/article/4837].

UNFCCC. 2007. Climate Change: Impacts, Vulnerabilities and Adaptation in D. Bonn, Germany. United Nations Framework Convention on Climate Change. 
Nepal Journal of Science and Technology Vol. 16, No.1 (2015) 59-68 